\title{
Effects of Hypothyroidism on Central and Peripheral Atherosclerosis in the Old Aged
}

\author{
Yașlı Hastalarda Hipotiroidizmin Santral ve Periferik Arter Aterosklerozuna Etkileri
}

\author{
(1) Volkan Atmışㄴ, (1) Berna Evranos Öğmen2, (1) Murat Faik Erdoğan33, (1) Teslime Atlı1 \\ ${ }^{1}$ Ankara University Faculty of Medicine, Department of Internal Medicine, Division of Geriatrics, Ankara, Turkey \\ ${ }^{2}$ Ankara Yıldırım Beyazıt University Faculty of Medicine, Department of Internal Medicine, Ankara, Turkey \\ ${ }^{3}$ Ankara University Faculty of Medicine, Department of Internal Medicine, Division of Metabolism, Ankara, Turkey
}

\section{Abstract}

Objectives: Aging is associated with an increased incidence of thyroid function abnormalities. Thyroid hormones have been shown to affect vascular hemodynamics and arterial stiffness. Arterial stiffness appears to be an essential risk factor for cardiovascular disease. The long-term effect of hypothyroidism on the development of the peripheral arterial disease is not well understood. Pulse wave velocity (PWV) is a simple, non-invasive marker of atherosclerosis that measures arterial stiffness. Ankle brachial index (ABI) is a non-invasive technique commonly used to detect peripheral vascular diseases. A limited number of studies evaluated hypothyroidism as a risk factor for both peripheral arterial disease and arterial stiffness in the old aged. We aimed to investigate this relationship in older patients and then compared with their younger counterparts.

Materials and Methods: A total of 22 patients $\geq 65$ years of age and 23 younger patients with hypothyroidism and 23 gender-matched, and body mass index-matched old aged individuals with euthyroidism as controls were enrolled in this study. Old aged patients with hypothyroidism were defined as group I, old aged individuals with euthyroidism were defined as group II, and younger patients with hypothyroidism were defined as group III. PWV was measured between the carotid and femoral arteries. ABI was measured by a handheld Doppler.

Results: PWV was similar (0.36) in older groups (groups I and II) and was lower $(\mathrm{p}<0.001)$ in group III. ABI measurements (left and right) were similar in all groups $(p>0.05)$. More than half of the patients with hypothyroidism had subclinical hypothyroidism, and this condition was similar in all groups $(p=0.26)$. We also compared patients with hypothyroidism (group I plus III) with older controls with euthyroidism (group II). Median age was higher in group II than that in group I plus III ( $p<0.001)$. PWV was higher in group II than that in group I plus III ( $p<0.001)$. Hypertension was more common in group II than in group I plus III $(p<0.001)$.

Conclusion: We did not find a relationship between hypothyroidism and atherosclerosis in old aged. PWV and hypertension were higher in older patients with hypothyroidism than in younger. Aging and hypertension increased PWV. Studies with larger series are needed to increase the reliability of these results.

Key Words: Hypothyroidism, Peripheral Arterial Disease, PWV, ABI, Arterial Stiffness, Old Aged

\section{Öz}

Amaç: Yaşlanma, tiroid fonksiyon bozukluğu sıklığının artması ile ilişkilidir. Tiroid hormonlarının vasküler hemodinamiği ve arter sertliğini etkilediği gösterilmiştir. Arteriyel sertlik, kardiyovasküler hastalıklar için önemli bir risk faktörü olarak görünmektedir. Hipotiroidizmin periferik arter hastalığının gelişimi üzerindeki uzun vadeli etkisi iyi anlaşılmamıştır. Nabız dalga hızı (NDH), arteriyel sertliği ölçen basit, invazif olmayan bir ateroskleroz belirtecidir. Ayak bileği-brakiyal indeks ( $A B I)$ periferik vasküler hastalıkları tespit etmek için yaygın olarak kullanılan invaziv olmayan bir tekniktir. Sınırlı sayıda çalışma yaşılıarda hipotiroidizmi periferik arter hastalığı ve arter sertliği açısından bir risk faktörü olarak değerlendirmiştir. Bu çalışmada yaşıı hastalarda bu ilişkiyi araştırmayı ve daha sonra genç kontrollerle karşılaştırmayı amaçladık.

Gereç ve Yöntem: Kırk Çalışmaya hipotiroidis olan 65 yaş üstü 22 hasta, 65 yaş altı 23 hasta ile cinsiyeti ve vücut kitle indeksi çalışma grubuyla benzer 65 yaş üstü 23 ötiroidik katılımcı alındı.yaşları 65, yaşları 23, hipotiroidizmi olan 23 genç Hipotiroidizmi olan yaşlı hastalar grup I, ötiroidisi

Address for Correspondence/Yazışma Adresi: Volkan Atmış MD

Ankara University Faculty of Medicine, Department of Internal Medicine, Division of Geriatrics, Ankara, Turkey

Phone: +90 3125083575 E-mail: volkanatmis@hotmail.com ORCID: orcid.org/0000-0002-0080-6448

Received/Geliş Tarihi: 07.08.2019 Accepted/Kabul Tarihi: 07.08.2019

๑Copyright 2019 Ankara University Faculty of Medicine

Journal of Ankara University Faculty of Medicine is published by Galenos Publishing House.

All content are under CC BY-NC-ND license. 
olan yaşılar grup II, hipotiroidizmi olan genç hastalar grup III olarak tanımlandı. Karotis ve femoral arterler arasında PWV ölçüldü. ABI el tipi bir Doppler ile ölçülmüştür.

Bulgular: LDL düzeyleri hipotiroidizmli hastalarda daha yüksek saptandı. Nabız dalga hızı değerleri arasında yaşlı kontrol ve yaşı hasta grubunda anlamlı fark saptanmadı. En düşük nabız dalga hızları genç hasta grubunda izlendi. Yaşlı gruplarla genç hasta grubu arasındaki fark anlamlıydı $(p=0,001)$. ABI ölçümleri arasında gruplar arasında anlamlı fark saptanmadı $(p>0,05)$. Grupların ABI değerleri periferik arter hastalığı için tanısal olmayan sınırlardaydı $(>0,9)$.

Sonuç: Yaşlı hipotiroidizmli hastalarda santral ve periferik ateroskleroz artışı izlenmedi.Bu konuda daha fazla sayıda kapsamlı çalışmalara ihtiyaç vardır.

Anahtar Kelimeler: Hipotiroidizm, Periferik Arter Hastalığı, PWV, ABI, Arteriyel Katılık, İleri Yaş

\section{Introduction}

Aging is associated with an increased incidence of thyroid function abnormalities. (1) An increased prevalence of overt hypothyroidism $(\mathrm{OH})$ and subclinical hypothyroidism $(\mathrm{SH})$ has been consistently reported with frequencies ranging from $0.5 \%$ to $5 \%$ for $\mathrm{OH}$ and from $5 \%$ to $20 \%$ for $\mathrm{SH}$ in women aged between 60 and 65 years. $(1,2)$ Older women are more likely to have thyroid dysfunction when compared with men (3).

Thyroid hormone has significant effects on both the heart and blood vessels. Thyroid hormones have been shown to affect vascular hemodynamics and arterial stiffness $(4,5)$. In patients with $\mathrm{OH}$, systemic vascular resistance is increased, and hypertension is approximately three times more common than in those who are euthyroid (6).

Arterial stiffness appears to be an essential risk factor for cardiovascular disease, and changes in arterial wall elasticity may occur during the early stages of atherosclerosis or even earlier. Pulse wave velocity (PWV) is a simple, noninvasive marker of atherosclerosis that measures arterial stiffness to serve as an indicator of the future outcome of atherosclerotic vascular disease (7). Of note, both the American Heart Association scientific statement and European expert consensus have recommended PWV as the gold standard for arterial stiffness with consideration to its high accuracy and applicability (8). Increased PWV is closely associated with increased cardiovascular events $(9,10)$.

The long-term effect of hypothyroidism on the development of the peripheral arterial disease is not well understood. Conflicting and inadequate evidence exists in the literature, and further studies are needed to clarify this association. The ankle-brachial index $(\mathrm{ABI})$ test is a noninvasive technique that is commonly used to detect peripheral vascular diseases.

In the following study, we test the hypothesis that hypothyroidism is associated with lower extremity arterial disease and arterial stiffness. A limited number of studies evaluated hypothyroidism as a risk factor for both peripheral arterial disease and arterial stiffness in the old age group. We aimed to investigate this relationship in old aged patients and then compared them with their younger counterparts.

\section{Materials and Methods}

This prospective study was conducted in the departments of geriatric medicine and endocrinology of a university hospital. Patients with hypothyroidism admitted to the clinic of geriatric medicine and endocrinology during a 6-monthperiod were enrolled. A total of 22 patients $\geq 65$ years old patients and 23 younger patients with hypothyroidism, and 23 gender-matched, and body mass index (BMI)-matched old aged euthyroid individuals as controls were enrolled in this study. Old aged individuals of the control group were recruited from volunteering hospital staffs' relatives and visitors. Old aged patients with hypothyroidism were defined as group I, old aged individuals with euthyroidism were defined as group II, and younger patients with hypothyroidism were defined as group III.

The control euthyroid older group consisted of patients with thyrotropin (TSH) levels of 0.5-5.0 $\mu \mathrm{lU} / \mathrm{ml}$. The hypothyroidism group consisted of patients with subclinical and clinical hypothyroidism. Subclinical hypothyroidism was diagnosed when TSH was 5.1-20 $\mu \mathrm{lU} / \mathrm{ml}$ with normal free thyroxine (FT4) and free triiodothyronine (FT3) levels (FT4; 0.9-1.7 ng/dL, FT3; 1.8-4.6 pg/mL). Clinical hypothyroidism was diagnosed when TSH was higher than $5.1 \mu \mathrm{lU} / \mathrm{ml}$ with low FT4 or FT3 level. Serum concentrations of $\mathrm{FT} 4, \mathrm{FT} 3$, and TSH were measured with the chemiluminescent immunometric assay.

Patients were excluded if they had diabetes mellitus; Stage 2 hypertension according to JNC 7; cerebral, coronary, and peripheral artery disease; and renal dysfunction (serum creatinine $>2.0 \mathrm{mg} / \mathrm{dL}$ ). The present study was approved by the Institutional Review Board of a University Medical School, and all subjects provided informed consent before entering the study.

Data of each patient and control subjects, including age, gender, and blood pressure, were recorded. Anthropometric variables, including BMI, waist circumference, hip circumference, and waist-to-hip ratio (WHR), were recorded correctly.

A venous blood sample was drawn from each patient and control group participants to evaluate TSH, FT4, FT3, highdensity lipoprotein (HDL), low-density lipoprotein (LDL), and triglyceride (TG) levels after overnight fasting. PWV and $A B I$ 
measurements were performed as determinants of vascular function.

Smoking status, history of hypertension, and use of antihypertensive and anti-dyslipidemic medications were asked and recorded.

This study is ethically approved by Local Ethics Committee with number 15973.

\section{Measurement of arterial stiffness (PWV)}

Central arterial stiffness was assessed using carotid-femoral pulse wave analysis. Examinations were conducted between 9 a.m. and 1 p.m. after a minimum of 5 minutes rest in a quiet room. The study subjects had abstained from smoking and intake of tea, coffee, or other caffeinated beverages for at least three hours before the start of examinations. At least two hours elapsed between breakfast and the examinations.

Femoral and carotid artery waveforms were consecutively obtained using the SphygmoCor apparatus and customized software. Continuous pulse pressure wave signals were recorded with a tonometer positioned at both the base of the right common carotid artery and over the femoral artery (Millar arterial pressure tonometer, SphygmoCor machine; PWV; PWV Inc., Westmead, Sydney, NSW, Australia). Distances from the carotid sampling sites to the manubrium sternum and from manubrium sternum to femoral artery were measured. The mean transit time $(t)$ between the peaks of simultaneously recorded waves was determined from 10 consecutive cardiac cycles. PWV was calculated from a distance between measurement points and the measured time delay as follows: $P W V=D / t(D$, distance in meters; $t$, time in seconds). Four measurements were recorded for each subject. A measurement was excluded if the pressure contour was of poor quality or a 15\% difference in heart rate was found between the carotid and femoral measurements. The average of the acceptable measurements was recorded as a subject's PWV. This methodology was previously described and validated. (11) All measurements were obtained by a single experienced technician.

\section{Measurement of peripheral arterial disease (ABI)}

As stated previously, all $A B I$ measurements were performed by the same experienced technician who underwent specific training. The technique described by Grenon et al. was used for the ABI test. (12) The measurement was performed while the patient was lying in supine position. Two metal plates of $80 \times$ $15 \mathrm{~cm}$ were placed at the head of the stretcher at an angle of $30^{\circ}$ to ensure arm comfort. For systolic pressure measurement, four new fully calibrated aneroid sphygmomanometers with Velcro cuffs were used (ERKA, D-83646, Germany). Cuff width was $12 \mathrm{~cm}$, and cuff length was $29-40 \mathrm{~cm}$. All four extremities of the patient were wrapped with cuffs at the same time, and during this process, the participants were allowed to rest for at least $5 \mathrm{~min}$. Both brachial pulses in the upper extremities and the tibialis anterior and tibialis posterior pulses in the lower extremities were recorded. Measurements were obtained using a handheld $8 \mathrm{MHz}$ Doppler instrument (Hadeco Echo Sounder ES-101EX, Japan). The first blood flow sound heard as the cuff was deflated was recorded. In the case of weak sounds, an earphone was used. The readings were started from the right arm, followed by the right ankle, left ankle, and left arm. The cycle was repeated to allow two values to be recorded for each vessel, and the mean of the two measurements was considered as the final result for the particular vessel.

$A B I$ was calculated based on the Trans-Atlantic Inter-Society Consensus Document on Management of Peripheral Arterial Disease II (TASC-II) guidelines (13). First, right and left ABI values were separately calculated by dividing the highest systolic blood pressures measured in each limb (a. tibialis posterior or a. tibialis anterior) to the highest systolic blood pressure measured in the right or left brachial artery. The lowest of the right and left $A B I$ values recorded were considered as the final $A B I$ value of the tested individual.

\section{Statistical Analysis}

Statistical analysis was performed using IBM Statistical Package for Social Sciences for Windows v25.0. (IBM Corp., Armonk, NY). The normality of the variable distributions was assessed using the Shapiro-Wilk test. Continuous data are given as means-standard deviations or medians (minimummaximum). The means of groups were compared using a oneway analysis of variance with a post hoc Tukey HSD test or the Kruskal-Wallis test according to the distribution of the data. Categorical variables were compared using the chi-square or Fisher's exact test. A value of $p<0.05$ was considered statistically significant.

\section{Results}

All demographic characteristics of patients are presented in Table 1. There was no statistically significant difference between the groups regarding gender ( $\mathrm{M}: \mathrm{F}$ ratio), BMI, WHR, and HDL level $(p>0.05)$. The mean age was $71.4 \pm 8.02$ years in the first group and $73.6 \pm 5.4$ years in the second group. Ages were similar in these two groups $(p=0.1)$. The median triglyceride level was similar in group I and group II $(\mathrm{p}=0.35)$ and was higher than the level in group III ( $p=0.01)$ (Table 1).

More than half of the patients with hypothyroidism had $\mathrm{SH}$, and this condition was similar in groups $(\mathrm{p}=0.26)$ (Table 2$)$. The mean age in the third group was $48.5 \pm 7.2$ years and was significantly low $(p<0.001)$. A subgroup analysis of data in old aged patients (groups I and II) is shown in Table 3a. 
A subgroup analysis of data in patients with hypothyroidism (group I and group III) is shown in Table 3b. The mean LDL level was similar in groups I and III ( $p=0.78)$ whereas it was lower in group II than in group I $(p=0.008)$. The TSH level was similar $(p=0.3)$ in younger and older patients with hypothyroidism, whereas it was higher $(p<0.001)$ than that in old aged individuals of the control group. Hypertension was more common in older groups (groups I and II) than group III $(p<0.001)$ and was similar in groups I and II ( $p=0.06)$. PWV was similar (0.36) in older groups (groups I and II) and was lower $(p<0.001)$ in group III. ABI measurements (left and right) were similar in all groups ( $p>0.05$ ). Also, smoking was similar in all groups $(p=0.06)$. Patients who used only statin, or only $A C E / A R B$, or only CCB were similar in all groups $(p=0.5)$. Patients who were treated with combination therapy with $A C E /$ $A R B$ and $C C B$, or $A C E / A R B$ and statins, or ACE/ARB plus CCB and a statin were similar in all groups $(p=0.5)$. Treatment with combination or single antihypertensive and antihyperlipidemic drug therapy was similar between groups.

We also compared hypothyroid patients (group I plus III) with euthyroid older controls (group II) (Table 4). Age was higher in group II than group I plus III $(p<0.001)$. PWV was higher in group II than group I plus III $(p<0.001)$. Hypertension disease was more common in group II than group I plus III $(p<0.001)$. $A B I$ (right and left), TG, LDL, HDL, BMI, WHR, smoking status were similar in patients with hypothyroidism and older controls with euthyroidism ( $p>0.05)$.

\section{Discussion}

We investigated PWV and $A B I$ in old patients with hypothyroidism, younger patients with hypothyroidism, and old

\begin{tabular}{llll}
\multicolumn{2}{c}{ Table 2: Classification of hypothyroid state of patients } & \\
& Group I (n=22) & $\begin{array}{l}\text { Group III } \\
(\mathbf{n = 2 3 )}\end{array}$ & p \\
\hline SH (TSH 5-10 $\mu \mathrm{lU} / \mathrm{mL})$ & $13(59.1 \%)$ & $16(69.6 \%)$ & \\
SH (TSH $10-20 \mu \mathrm{lU} / \mathrm{mL})$ & $1(4.5 \%)$ & $3(13 \%)$ & 0.26 \\
OH & $8(36.4 \%)$ & $4(17.4 \%)$ &
\end{tabular}

$\mathrm{OH}$ : Overt hypothyroidism, SH: Subclinical hypothyroidism

Table 1: Demographic and measurement data of patients

\begin{tabular}{|c|c|c|c|c|}
\hline & Group I (n=22) & Group II $(n=23)$ & Group III $(n=23)$ & $\mathbf{p}$ \\
\hline Female/Male & $17 / 5(77.3 \%)$ & $14 / 9(60.9 \%)$ & $19 / 4(82.6 \%)$ & 0.22 \\
\hline Age (years) & $71.4 \pm 8.02$ & $73.6 \pm 5.4$ & $48.5 \pm 7.2$ & $<0.001$ \\
\hline $\mathrm{PWV}(\mathrm{m} / \mathrm{s})$ & $11.23 \pm 3.35$ & $12.1 \pm 2.7$ & $7.6 \pm 1.6$ & $<0.001$ \\
\hline Triglyceride (mg/dL) & 164.5(71-289) & $120(32-380)$ & $83(46-357)$ & 0.01 \\
\hline LDL (mg/dL) & $163.15 \pm 58.2$ & $121.8 \pm 29.5$ & $134 \pm 44.2$ & 0.01 \\
\hline $\mathrm{HDL}(\mathrm{mg} / \mathrm{dL})$ & $49.4 \pm 13.2$ & $48.4 \pm 11.7$ & $50.8 \pm 14.9$ & 0.85 \\
\hline TSH $(\mu \mathrm{IU} / \mathrm{mL})$ & $8.57(5.2-100)$ & $1.35(0.48-2.8)$ & $8.33(5.2-100)$ & 0.001 \\
\hline $\mathrm{FT} 4$ (ng/dL) & $7.2 \pm 3.3$ & $10.7 \pm 1.7$ & $8.3 \pm 3.03$ & 0.051 \\
\hline ABI (Right) (Mean) & $1.05 \pm 0.22$ & $1.09 \pm 0.13$ & $1.06 \pm 0.11$ & 0.74 \\
\hline ABI (Left) (Mean) & $1.05 \pm 0.24$ & $1.12 \pm 0.10$ & $1.11 \pm 0.10$ & 0.25 \\
\hline $\mathrm{SBP}(\mathrm{mmHg})$ & $130(60-160)$ & $130(120-160)$ & $120(110-150)$ & 0.11 \\
\hline $\mathrm{DBP}(\mathrm{mmHg})$ & $80(40-100)$ & $80(70-100)$ & $80(60-100)$ & 0.42 \\
\hline BMI $\left(\mathrm{kg} / \mathrm{m}^{2}\right)$ & $31.1 \pm 6.4$ & $28.4 \pm 5$ & $28.4 \pm 6$ & 0.24 \\
\hline WHR & $0.97 \pm 0.06$ & $0.92 \pm 0.07$ & $0.92 \pm 0.06$ & 0.07 \\
\hline \multicolumn{5}{|l|}{ Comorbidities } \\
\hline Hypertension & $50 \%$ & $78.3 \%$ & $8.7 \%$ & $<0.001$ \\
\hline Smoking & $23.8 \%$ & $10.5 \%$ & $42.9 \%$ & 0.06 \\
\hline \multicolumn{5}{|l|}{ Medication } \\
\hline Only Statin & 2 & 3 & 1 & \multirow{6}{*}{0.5} \\
\hline Only ARB/ACE inhibitor & 7 & 8 & 0 & \\
\hline Only CCB & 0 & 2 & 0 & \\
\hline ARB/ACE inhibitor + CCB & 2 & 4 & 0 & \\
\hline ARB/ACE inhibitor + Statin & 2 & 1 & 1 & \\
\hline ARB/ACE inhibitör + CCB + Statin & 0 & 2 & 0 & \\
\hline
\end{tabular}

PWV, pulse wave velocity, LDL: Low-density lipoprotein, HDL: High-density lipoprotein, TSH: Thyroid stimulating hormone, FT4: Free thyroxin, ABI: Ankle-brachial index, SBP: Systolic blood pressure, DBP: Diastolic blood pressure, BMI: Body mass index, WHR: Waist-hip ratio, ACE: Angiotensin converting enzyme, ARB: Angiotensin receptor blocker, CCB: Calcium channel blocker 
aged controls. Our first significant finding is that there was no difference in PWV and $A B I$ when comparing old aged patients with hypothyroidism with old aged controls. Our second significant finding is that PWV was higher in older patients with hypothyroidism than in younger patients with hypothyroidism, whereas $A B I$ was similar in these groups.

\begin{tabular}{|c|c|c|c|}
\hline & Group I $(n=22)$ & $\begin{array}{l}\text { Group II } \\
(n=23)\end{array}$ & $\mathbf{p}$ \\
\hline Age (years) & $71.4 \pm 8.02$ & $73.6 \pm 5.4$ & 0.10 \\
\hline Triglyceride (mg/dL) & 164.5 (71-289) & $120(32-380)$ & 0.35 \\
\hline LDL (mg/dL) & $163.15 \pm 58.18$ & $121.8 \pm 29.5$ & 0.008 \\
\hline TSH $(\mu \mathrm{IU} / \mathrm{ml})$ & $8.57(5.2-100)$ & $1.35(0.48-2.8)$ & $<0.001$ \\
\hline $\mathrm{PWV}(\mathrm{m} / \mathrm{s})$ & $11.2 \pm 3.3$ & $12.1 \pm 2.7$ & 0.36 \\
\hline Hypertension & $50 \%$ & $78.3 \%$ & 0.06 \\
\hline
\end{tabular}

Table 3b: Subgroup analysis of data in hypothyroid patients

\begin{tabular}{|llll} 
& $\begin{array}{l}\text { Group I } \\
(\mathbf{n = 2 2 )}\end{array}$ & $\begin{array}{l}\text { Group III } \\
(\mathbf{n = 2 3 )}\end{array}$ & $\mathbf{p}$ \\
\hline Age (years) & $71.4 \pm 8.02$ & $48.5 \pm 7.2$ & $<\mathbf{0 . 0 0 1}$ \\
\hline Triglyceride(mg/dL) & $164.5(71-289)$ & $83(46-357)$ & $\mathbf{0 . 0 0 4}$ \\
\hline LDL $(\mathrm{mg} / \mathrm{dL})$ & $163.15 \pm 58.2$ & $134 \pm 44.2$ & 0.78 \\
\hline TSH $(\mu \mathrm{lU} / \mathrm{mL})$ & $8.57(5.2-100)$ & $8.33(5.2-100)$ & 0.3 \\
\hline $\mathrm{PWV}(\mathrm{m} / \mathrm{s})$ & $11.2 \pm 3.3$ & $7.6 \pm 1.6$ & $<\mathbf{0 . 0 0 1}$ \\
\hline Hypertension & $50 \%$ & $8.7 \%$ & $\mathbf{0 . 0 0 3}$
\end{tabular}

LDL: Low density lipoprotein, TSH: Thyroid stimulating hormone, PWV: Pulse wave velocity

Table 4: Comparison of hypothyroid patients (group I + III) with older euthyroid controls (group II)

\begin{tabular}{|llll} 
& $\begin{array}{l}\text { Hypothyroidism } \\
\text { (Group I }+ \\
\text { Group III) } \\
(\mathbf{n = 4 5 )}\end{array}$ & $\begin{array}{l}\text { Euthyroidism } \\
\text { Group II } \\
(\mathbf{n = 2 3 )}\end{array}$ & $\mathbf{p}$ \\
\hline Age (years) & $59.7 \pm 13.8$ & $73.6 \pm 5.4$ & $<\mathbf{0 . 0 0 1}$ \\
\hline PWV (m/s) & $9.24 \pm 3.1$ & $12.1 \pm 2.7$ & $<\mathbf{0 . 0 0 1}$ \\
\hline ABI (right) & $1.06 \pm 0.17$ & $1.09 \pm 0.13$ & 0.44 \\
\hline ABI (left) & $1.07 \pm 0.18$ & $1.12 \pm 0.1$ & 0.31 \\
\hline Triglyceride (mg/dL) & $107(46-357)$ & $120(32-380)$ & 0.55 \\
\hline LDL (mg/dL) & $149.4 \pm 53.3$ & $121.8 \pm 29.5$ & 0.10 \\
\hline HDL (mg/dL) & $50.1 \pm 13.9$ & $48.4 \pm 11.7$ & 0.64 \\
\hline Smoking & $33.3 \%$ & $10.5 \%$ & 0.11 \\
\hline Hypertension & $28.9 \%$ & $78.3 \%$ & $<\mathbf{0 . 0 0 1}$ \\
\hline BMI (Mean) & $29.5 \pm 6.3$ & $28.4 \pm 5$ & 0.6 \\
\hline WHR (Mean) & $0.95 \pm 0.06$ & $0.92 \pm 0.07$ & 0.16 \\
\hline
\end{tabular}

PWV: Pulse wave velocity, ABI: Ankle brachial index, LDL: Low density lipoprotein, HDL: High density lipoprotein, BMI: Body mass index, WHR: Waist-to-hip ratio
In this study, most patients with hypothyroidism had subclinical hypothyroidism with TSH $<10 \mu \mathrm{IU} / \mathrm{mL}$ (Table 2). A cross-sectional study conducted in 755 subjects with $\mathrm{SH}$ aged $>65$ years found a nonsignificant odds ratio (OR) (1.02) for chronic heart disease (CHD), although the risk for CHD became significant for those with high ( $>10 \mathrm{mU} / \mathrm{L}$ ) serum TSH values (14). Kvetny et al. (15) in a cross-sectional study in 1374 subjects (age range, 20-69 years) from the general population found that SH provided a significant OR (3.3) for cardiovascular disease (CVD) including CHD only in males aged $<50$ years, whereas no significant relationship was present in the overall population. Finally, in a large US cohort study in individuals aged 65 years or older, no difference was found in the prevalence of CHD or CVD between a group of 496 subjects with SH (mean age $=73.2$ years) and the euthyroid controls both at baseline and during a 13-year follow-up (16). Further support for this concept comes from a recent paper by Gussekloo et al. (17), who found a reduction of cardiovascular and all-cause mortality in subjects with mild hypothyroidism aged $>85$ years.

In contrast to the papers mentioned above, Masaki et al. (18) showed that raised arterial stiffness using the cardioankle vascular index in old aged patients with subclinical hypothyroidism. Tudoran et al. (19) demonstrated that significant alterations of arterial stiffness observed in all hypothyroid patients (subclinical, overt, and severe hypothyroidism) and endothelial dysfunction was strongly related to the severity of thyroid disease.

However, the reason for the discrepant results found in the studies mentioned above remains unknown; possible explanations include type (longitudinal vs cross-sectional) and dimension of the studies, ethnic and environmental factors, and, most importantly, age. This characteristic suggests that there are age-dependent variations in sensitivity to the detrimental effects of mild thyroid failure on coronary flow. Subtle hypothyroidism could be protective for cardiovascular death in the oldest population (17).

Mazeffi et al. (20) showed, no significant association between hypothyroidism and lower extremity arterial disease. One large prospective study followed 338 patients with subclinical hypothyroidism and 2392 patients with euthyroidism over 4 years and found no increased risk of peripheral arterial disease during that time (21). The publication from the Inter-Society Consensus for the Management of Peripheral Arterial Disease does not define hypothyroidism as a risk factor associated with peripheral arterial disease, although some limited evidence suggests that there may be an association between the two. (13) For example, Mya et al. (22) showed an association between subclinical hypothyroidism and symptomatic PAD in senior men and women. In a second study, women with peripheral 
arterial disease were found to have significantly higher serum thyrotropin levels than controls (23).

In this study, PWV and hypertension were higher in older patients with hypothyroidism than in younger patients with hypothyroidism. Hypothyroidism causes a decrease in the release of endothelium drived relaxing factor (EDRF) resulting in endothelial dysfunction, systemic vascular resistance increases and diastolic hypertension occurs. Response to catecholamin mediated increase in inotropy is altered. Decreased response to beta-adrenergic stimulation results in cardiovascular autonomic dysfunction. Thyroid hormones regulate lipid and glucose metabolism. Hypothyroidism associated hyperlipidemia, metabolic syndrome, hypertension and endothelial dysfunction play a major role in increased cardiovascular risk and arterial stiffness. Hypertension is associated with increased stiffness of the aorta and large muscular arteries (24). Arterial stiffness was shown to be an independent predictor of cardiovascular disease in patients with hypertension. (25) In the study by Zhang et al. (26) showed increased PWV with aging. Moreover, hypertension was a risk factor for increased arterial stiffness in different age groups. With advancing age, most individuals experience stiffening of large conduit arteries, albeit at different rates. In agreement with our findings, Tanaka et al. $(27,28)$ showed progressive PWV increases with advancing age.

\section{Study Limitations}

The limitation of this study was the small number of patients in the groups. However, it is not common to encounter patients with no history of coronary artery disease, peripheral arterial disease, and diabetes mellitus, which are often seen in old aged patients. Some patients were using drugs that could affect the formation of arterial disease. We were fortunate that the distribution of such drug use was similar in groups. PWV and $A B I$ assessment in old aged patients is an essential feature for its clinical application. Lastly, Although the anti-thyroid peroxidase and anti-thyroglobulin autoantibodies were lacking in the study, autoimmunity and increased inflammation play a role in atherosclerosis. It is well-known that autoimmunity is associated with elevated cytokine levels such as TNF-alpha and IL-6. This as a potential underlying mechanism of vascular dysfunction in autoimmune hypothyroidism, lack of autoantibodies as a limitation of this study. However, our operators were adequately trained in the relevant techniques. It would be better if our results were supported with additional studies that included a larger number of patients.

\section{Conclusion}

We found that $A B I$ and PWV did not change in old aged patients with hypothyroidism, predominantly subclinical hypothyroidism when compared with old aged controls.
The increase in PWV was associated with both aging and hypertension. Studies with larger series are needed to increase the reliability of these results.

\section{Ethics}

Ethics Committee Approval: This study is ethically approved by local ethics committee with number 15973.

Informed Consent: All subjects provided informed consent before entering the study.

Peer-review: Externally peer-reviewed.

\section{Authorship Contributions}

Concept: V.A., B.E.Ö., M.F.E., T.A., Design: V.A., B.E.Ö., M.F.E., T.A., Data Collection or Processing: V.A., B.E.Ö., M.F.E., T.A., Analysis or Interpretation: V.A., B.E.Ö., M.F.E., T.A., Literature Search: V.A., B.E.Ö., M.F.E., T.A., Writing: V.A., B.E.Ö., M.F.E., T.A.

Conflict of Interest: No conflict of interest was declared by the authors.

Financial Disclosure: The authors declared that this study received no financial support.

\section{References}

1. Mariotti S, Franceschi C, Cossarizza A, et al. The aging thyroid. Endocr Rev. 1995; 16:686-715.

2. Canaris GJ, Manowitz NR, Mayor G, et al. The Colorado thyroid disease prevalence study. Arch Intern Med. 2000;160:526-534.

3. Helfand M, Redfern CC. Clinical guideline, part 2. Screening for thyroid disease: an update. American College of Physicians. Ann Intern Med. 1998;129:144-158.

4. Napoli R, Biondi B, Guardasole V, et al. Impact of hyperthyroidism and its correction on vascular reactivity in humans. Circulation. 2001;104:30763080.

5. Sato $Y$, Nakamura R, Satoh $M$, et al. Thyroid hormone targets matrix Gla protein gene associated with vascular smooth muscle calcification. Circ Res. 2005; $97: 550-557$

6. Endo T, Komiya I, Tsukui T, et al. Re-evaluation of a possible high incidence of hypertension in hypothyroid patients. Am Heart J. 1979;98:684-688.

7. Yamashina A, Tomiyama $H$, Arai $T$, et al. Brachial-ankle pulse wave velocity as a marker of atherosclerotic vascular damage and cardiovascular risk. Hypertens Res. 2003;26:615-622.

8. Mancia G, Fagard R, Narkiewicz K, et al. 2013 ESH/ESC Guidelines for the management of arterial hypertension: the Task Force for the management of arterial hypertension of the European Society of Hypertension (ESH) and of the European Society of Cardiology (ESC). J Hypertens. 2013;31:12811357.

9. Hamilton PK, Lockhart CJ, Quinn CE, et al. Arterial stiffness: clinical relevance, measurement and treatment. Clin Sci (Lond). 2007;113:157-170.

10. Lane HA, Smith JC, Davies JS. Noninvasive assessment of preclinical atherosclerosis. Vasc Health Risk Manag. 2006;2:19-30.

11. Kelly RP, Millasseau SC, Ritter JM, et al. Vasoactive drugs influence aortic augmentation index independently of pulse-wave velocity in healthy men. Hypertension. 2001;37:1429-1433.

12. Grenon SM, Gagnon J, Hsiang Y. Video in clinical medicine. Anklebrachial index for assessment of peripheral arterial disease. N Engl J Med. 2009;361:e40.

13. Norgren L, Hiatt WR, Dormandy JA, et al. Inter-Society Consensus for the Management of Peripheral Arterial Disease (TASC II). Eur J Vasc Endovasc Surg. 2007;331:S1-75. 
14. Lindeman RD, Romero $\sqcup$, Schade DS, et al. Impact of subclinical hypothyroidism on serum total homocysteine concentrations, the prevalence of coronary heart disease (CHD), and CHD risk factors in the New Mexico Elder Health Survey. Thyroid. 2003;13:595-600.

15. Kvetny J, Heldgaard PE, Bladbjerg EM, et al. Subclinical hypothyroidism is associated with a low-grade inflammation, increased triglyceride levels and predicts cardiovascular disease in males below 50 years. Clin Endocrinol (0xf). 2004;61:232-238.

16. Cappola AR, Fried LP, Arnold AM, et al. Thyroid status, cardiovascular risk, and mortality in older adults. JAMA. 2006;295:1033-1041.

17. Gussekloo J, van Exel E, de Craen AJ, et al. Thyroid status, disability and cognitive function, and survival in old age. JAMA. 2004;292:2591-2599.

18. Masaki M, Komamura $K$, Goda $A$, et al. Elevated arterial stiffness and diastolic dysfunction in subclinical hypothyroidism. Circ J. 2014;78:14941500.

19. Tudoran $M$, Tudoran C. Particularities of endothelial dysfunction in hypothyroid patients. Kardiol Pol. 2015;73:337-343.

20. Mazzeffi MA, Lin HM, Flynn BC, et al. Hypothyroidism and the risk of lower extremity arterial disease. Vasc Health Risk Manag. 2010;6:957-962.

21. Rodondi $N$, Newman $A B$, Vittinghoff $E$, et al. Subclinical hypothyroidism and the risk of heart failure, other cardiovascular events, and death. Arch Intern Med. 2005;165:2460-2466.
22. Mya MM, Aronow WS. Increased prevalence of peripheral arterial disease in older men and women with subclinical hypothyroidism. J Gerontol A Biol Sci Med Sci. 2003;58:68-69.

23. Powell J, Zadeh JA, Carter G, et al. Raised serum thyrotrophin in women with peripheral arterial disease. Br J Surg. 1987;74:1139-1141.

24. Mulvany MJ. Small artery remodeling in hypertension. Curr Hypertens Rep. 2002;4:49-55.

25. Boutouyrie $\mathrm{P}$, Tropeano Al, Asmar R, et al. Aortic stiffness is an independent predictor of primary coronary events in hypertensive patients: a longitudinal study. Hypertension. 2002;39:10-15.

26. Zhang YJ, Wu SL, Li HY, et al. [Comparison of arterial stiffness in nonhypertensive and hypertensive population of various age groups]. Zhonghua Xin Xue Guan Bing Za Zhi. 2018;46:56-63.

27. Tanaka H, DeSouza CA, Seals DR. Absence of age-related increase in central arterial stiffness in physically active women. Arterioscler Thromb Vasc Biol. 1998;18:127-132.

28. Tanaka H, Dinenno FA, Monahan KD, Clevenger CM, DeSouza CA, Seals DR. Aging, habitual exercise, and dynamic arterial compliance. Circulation. 2000;102:1270-1275.. 